\title{
Alleviating Malnutrition among Rural Children
}

\author{
Shradha Trivedi ${ }^{1}$, Sunita Mishra ${ }^{2}$ \\ ${ }^{1}$ Student, Department of Food \& Nutrtion, School of Home Science, \\ Babasaheb Bhimrao Ambedkar University (Central University), Vidhya vihar, Raebareli Road, Lucknow - 226025 Uttar Pradesh , India. \\ ${ }^{2}$ Professor, Department of Food \& Nutrtion, School of Home Science, \\ Babasaheb Bhimrao Ambedkar University (Central University), Vidhya vihar, Raebareli Road, Lucknow - 226025 Uttar Pradesh, India
}

\begin{abstract}
Malnutrition or malnourishment is a condition that results from eating a diet in which nutrients are either not enough or are too much such that the diet causes health problems. It may involve calories, protein, carbohydrate, vitamins or minerals. Children are the vanguard and supreme powers of the world of tomorrow. The health of children is of fundamental importance. Without ensuring optimal child growth and development significantly will unsuccessful. Good nutrition is a basic requirement for good health. Therefore, sound knowledge of the needs of children is essential for guiding them properly. Keeping in view, present proposal has been framed to identify and eradicated various indicators which lead to poor nutritional status and linear growth retardation. Anthropometric assessment of children which includes height, weight, MUAC, skin thickness will be performed.
\end{abstract}

Keywords: Malnutrition, anthropometric measurement

\section{Introduction}

Children are the vanguard and supreme powers of the world of tomorrow. The health of children is of fundamental importance. Without ensuring optimal child growth and development their progress was significantly unsuccessful. Good nutrition is a basic requirement for good health. Therefore, sound knowledge of the needs of children is essential for guiding them properly. Keeping in view, present proposal has been framed to identify and eradicated various indicators which lead to poor nutritional status and linear growth retardation. Anthropometric assessment of children which includes height, weight, MUAC, skin thickness was performed.

Malnutrition or malnourishment is a condition that results from eating a diet in which nutrients are either not enough or are too much such that the diet causes health problems. It may involve calories, protein, carbohydrate, vitamins or minerals.

Malnutrition in children - here understood as under nutrition - is common globally and results in both short and long term irreversible negative health outcomes including stunted growth which may also be linked to cognitive development deficits, underweight and wasting. The World Health Organization (WHO) estimates that malnutrition accounts for 54 percent of child mortality worldwide, about 1 million children. Another estimate also by WHO states that childhood underweight is the cause for about $35 \%$ of all deaths of children under the age of five years worldwide.

There are three commonly used measures for detecting malnutrition in children:

- Stunting (extremely low height for age),

- Underweight (extremely low weight for age), and

- Wasting (extremely low weight for height).

These measures of malnutrition are interrelated, but studies for the World Bank found that only $9 \%$ of children exhibit stunting, underweight, and wasting.
Children with severe acute malnutrition are very thin, but they often also have swollen hands and feet, making the internal problems more evident to health workers. Children with severe malnutrition are very susceptible to infection.

Under nutrition in children causes direct structural damage to the brain and impairs infant motor development and exploratory behaviour. Children who are undernourished before age two and gain weight quickly later in childhood and in adolescence are at high risk of chronic diseases related to nutrition

\section{Objectives}

1) To identify linear growth retarded (stunted) children (1-6 yrs) by using anthropometric parameters.

2) To improve health based approach among malnourished children by providing health based lectures.

\section{Methodology}

The time taken for the study was one year that is July 2016 to may 2017.

The approach for this study was purposively one. By using questionnaire schedule.

The sample size of the study was restricted up to 100 samples.

Purposive random sampling method was used to collect the sample for this study. Sample comprise of 100 school going children's including boys and girls from Chandraval (Bijnaur) and Noorpur Bhadarsa (Bijnaur)..

\subsection{Tool of the Study}

Anthropometric measurements- For anthropometric measurement (weight, height, waist and hip circumference) the following equipment is needed (Body tapemeasure, Weight machine).

Volume 6 Issue 12, December 2017 
International Journal of Science and Research (IJSR)

ISSN (Online): 2319-7064

Index Copernicus Value (2016): 79.57 | Impact Factor (2015): 6.391

\subsection{Statistical analysis}

SPSS version 20 was used to draw meaningful inferences from the collected raw data.

\section{Result \& Discussion}

Distribution of respondent according to age:

\begin{tabular}{|c|c|c|c|}
\hline S. no. & Age (year) & Frequency & Percentage (\%) \\
\hline 1. & $1-2$ & 3 & 3.0 \\
\hline 2. & $2-3$ & 6 & 6.0 \\
\hline 3. & $3-4$ & 28 & 28.0 \\
\hline 4. & $4-5$ & 27 & 27.0 \\
\hline 5. & $5-6$ & 36 & 36.0 \\
\hline & Total & 100 & 100.0 \\
\hline
\end{tabular}

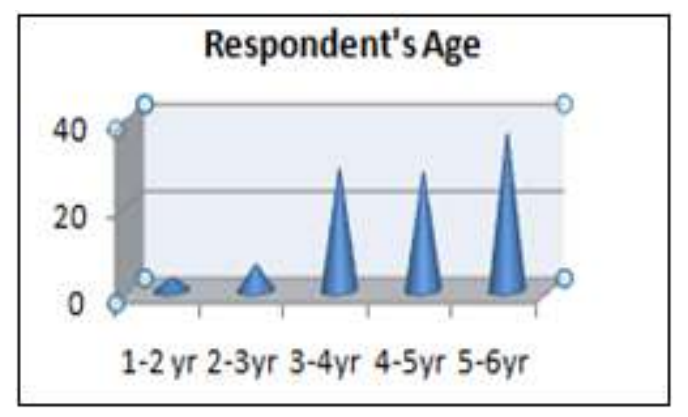

Above figure shows that the $3.0 \%$ children belong to age of 1-2 year, $6.0 \%$ children belong to $2-3$ year, $28.0 \%$ children belong to $3-4$ year, $27.0 \%$ children belong to $4-5$ year and $38.0 \%$ children belongs to the age of 5-6 year. Thus it was found that mazority of the respondent were in the age-group of 5-6 years.

\section{Distribution of respondent according to age:}

\begin{tabular}{|c|c|c|c|}
\hline S.no. & Gender & Frequency & Percentage (\%) \\
\hline 1. & Male & 61 & $61.0 \%$ \\
\hline 2. & Female & 39 & $39.0 \%$ \\
\hline & Total & 100 & $100 \%$ \\
\hline
\end{tabular}

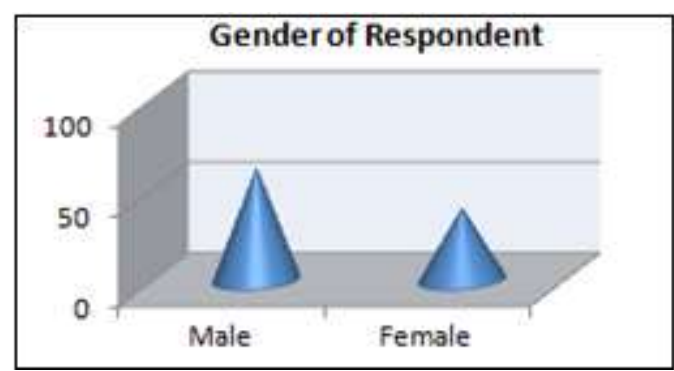

The result indicates that majorities $61 \%$ of the respondent sample were male and $39 \%$ respondent sample were female in the age group of 1-6 year.

Distribution of respondent's mother's qualification

\begin{tabular}{|c|c|c|c|}
\hline S.no. & Qualification & Frequency & Percentage (\%) \\
\hline 1. & Primary & 4 & $4.0 \%$ \\
\hline 2. & Middle & 17 & $17.0 \%$ \\
\hline 3. & Secondary & 69 & $69.0 \%$ \\
\hline 4. & Graduation & 10 & $10.0 \%$ \\
\hline & Total & 100 & $100 \%$ \\
\hline
\end{tabular}

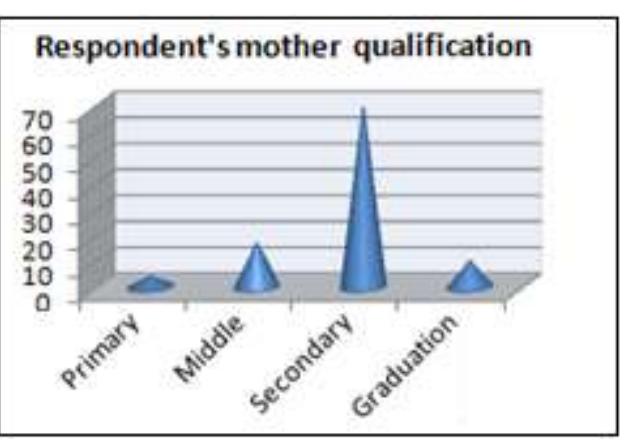

The above figure shows that only $10 \%$ respondent's mother were graduate. Majority of the respondent's mother did higher secondary whereas $4 \%$ respondent's mother did only primary and $17 \%$ respondent's mother did middle.

Distribution of the respondent on the basis of type of family

\begin{tabular}{|c|c|c|c|}
\hline S.no. & Type of family & Frequency & Percentage (\%) \\
\hline 1. & Nuclear & 23 & $23.0 \%$ \\
\hline 2. & Joint & 77 & $77.0 \%$ \\
\hline & Total & 100 & $100 \%$ \\
\hline
\end{tabular}

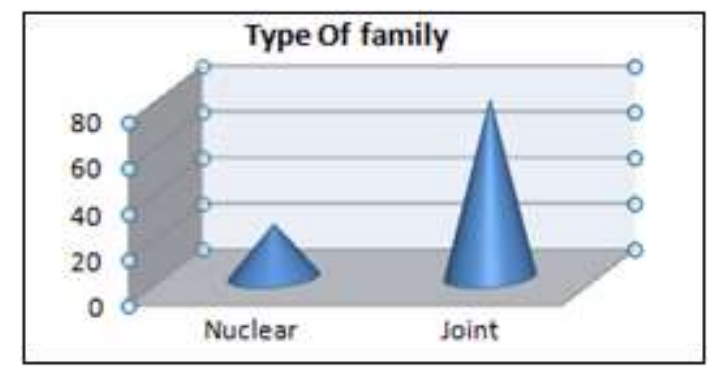

The above figure shows that $23 \%$ of respondent belong to the nuclear family and $77 \%$ of respondent were belong to the joint family. Thus it was found that the majority(77\%) of respondent were belonging to joint family

Distribution of the respondent according to BMI of rural children between the age of 0-6

\begin{tabular}{|c|c|c|c|c|c|c|c|c|c|}
\hline \multirow{3}{*}{$\begin{array}{c}\text { S. } \\
\text { no. }\end{array}$} & \multirow{3}{*}{$\begin{array}{c}\text { Age } \\
\text { BMI } \\
\text { range } \\
\mathrm{kg} / \mathrm{m}^{2}\end{array}$} & \multirow{2}{*}{\multicolumn{2}{|c|}{$\begin{array}{c}\text { Severe } \\
\text { Thinness }\end{array}$}} & \multirow{2}{*}{\multicolumn{2}{|c|}{\begin{tabular}{|c|}
$\begin{array}{c}\text { Moderate } \\
\text { Thinness }\end{array}$ \\
$16.00-16.99$ \\
\end{tabular}}} & \multicolumn{2}{|c|}{ Mild Thinness } & \multicolumn{2}{|c|}{ Normal } \\
\hline & & & & & & 7. & 49 & 18.5 & 24.99 \\
\hline & & $\mathrm{N}$ & $\%$ & & $\%$ & $\mathrm{~N}$ & $\%$ & $\mathrm{~N}$ & $\%$ \\
\hline 1 & 1 year & & & & & & 50 & 1 & 50 \\
\hline 2 & & & & & & 5 & $\%$ & 2 & $28.57 \%$ \\
\hline 3 & & & & & & & & 5 & \\
\hline 4 & 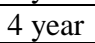 & & 12 & & $25 \%$ & 11 & & 9 & $28.12 \%$ \\
\hline 5 & 5 year & 1 & $4.70 \%$ & 9 & $42.90 \%$ & 7 & $33.33 \%$ & 4 & $19.07 \%$ \\
\hline 6 & 6 year & & $14.29 \%$ & & $3.57 \%$ & 5 & $5.72 \%$ & 3 & 21. \\
\hline
\end{tabular}

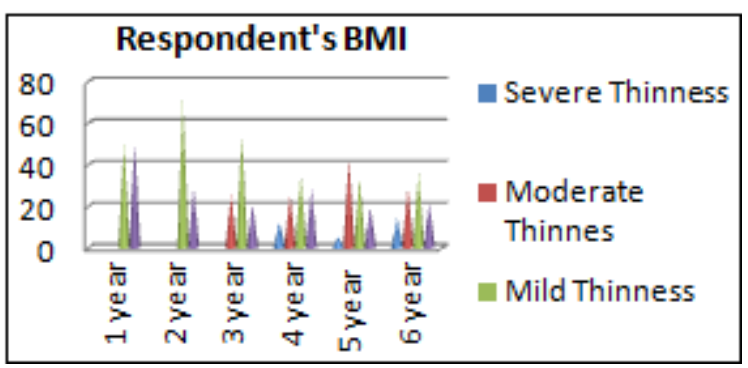

\section{Volume 6 Issue 12, December 2017}




\section{International Journal of Science and Research (IJSR) \\ ISSN (Online): 2319-7064 \\ Index Copernicus Value (2016): 79.57 | Impact Factor (2015): 6.391}

The above figure shows the BMI (Body Mass Index) of rural children by WHO standard measure values.

Among 1 year of age category only one (50\%) respondent was found mild thinness and one $(50 \%)$ respondent was found normal category whereas moderate and severe thinness category were found nil. Among 2 year of age 5 $(71.53 \%)$ respondent were found mild thinness and 2 $(28.57 \%)$ respondent were found normal category whereas moderate and severe thinness category were found nil. Among 3 years of age $6(25 \%)$ respondent were found moderate thinness category, $13(54.17 \%)$ respondent were found mild thinness and $5(20.83 \%)$ respondent were found normal category whereas severe thinness category were found nil. Among 4 year of age category 4 (12.5\%) respondent were found severe thinness , $8(25 \%)$ respondent were found moderate thinness category, 11 (34.38\%) respondent were found mild thinness and 9 (28.12\%) respondent were found normal category. Among 5 year of age category only $1(04.7 \%)$ respondent were found severe thinness , 9 (42.9\%) respondent were found moderate thinness category, $7(33.33 \%)$ respondent were found mild thinness and $4(19.07 \%)$ respondent were found normal category. Among 6 year of age category only 2 (14.29\%) respondent were found severe thinness , 4 (28.57\%) respondent were found moderate thinness category, 5 $(35.72 \%)$ respondent were found mild thinness and 3 $(21.42 \%)$ respondent were found normal category.

\section{Conclusion}

Childhood undernutrition includes fatal growth retardation, stunting, wasting and deficiency of vitamins along with suboptimum breastfeeding is a cause if majority of all children death. Childhood undernutrition is known to be at an increased risk of death. Nutritional status indicators especially bio-markers can be used to identified those infants and children at higher risk of dying due to morbidity and mortality.

Child malnutrion impacts cognitive function and contributes to poverty through impeding individuals' ability to lead productive lives. The health of children is of fundamental importance.. During early age years, children begin to establish habits for eating and hygiene that stick with them for developing for their entire lives. If children establish healthy habits, their risk for developing many chronic disease will be greatly decreased. On the other hand improper diet and unhygienic activity children set the stage for health problems in adulthood.

\section{Recommendation}

1) Nutritional awareness programmes should be organized for mothers in the rural areas of Bijnaur, Lucknow district.

2) Parents must play their part as well, by providing healthy foods in the home. Although many societal factors affect children's eating and activity habits, parents can exerts a profound influence on their children by promoting healthy foods and an active lifestyle from an early age and by serving as role models, the report says, parents can encourage their children to develop a healthy, varied diet by introduced new foods in a persistent but no coercive way.

\section{References}

[1] Indian children. Public Health.;113:69-72.

[2] Mishra et at (2014) Malnutrition among School Children of Lucknow Sunita International Journal of Science and Research (IJSR) ISSN (Online): 2319-7064 Impact Factor (2012): 3.358

[3] Mishra S. (2013) "Food". UGC net study manual home Science. Selective and scientific book publisher \&distributer. PP. 2-7.

[4] Mishra S., et at (2007), "Nutritional anthropometry and preschool child feeding practices in working mother of central Orissa." Study of home community science.

[5] S. Mishra (2005) "Assessment of malnutrition and remedial measures to improve the quality of life of children of Central Orissa" Indian journal of preventive \& social medicine 37(1\&2),25-31.

[6] Mishra et al (2014)"Fast food Consumption pattern and Obesity among school going in Lucknow District" International Journal of Science \& research (IJSR)3 $1672-1674$

[7] Mishra (2007) "Nutritional anthropometry and preschool child feeding practices in working mothers of cetral Orissa" stud Home Comm Sci 1(2) 139-144 